\title{
UWB Microstrip Line Feeding Planar Modified Circular Antenna
}

\author{
Pillalamarri L.
}

Department of Electronics and Communication Engineering, Radio Frequency and Microwave Laboratory, IIT Hyderabad, Telanagana-State, India

\section{Article info:}

Paper received:

The final version of the paper received:

Paper accepted online:
July 5,2017

December 12, 2017

February 28, 2018
Corresponding Author's Address: laxmanpillalamarri85@gmail.com

\begin{abstract}
In this paper we have investigated compact printed semicircular disc monopole antenna, which is basically printed microstrip antenna with etched ground plane for UWB applications. In particular we have simulated very compact semicircular disc monopole antennas for UWB communication. Simple rectangular microstrip line is used for feeding the printed monopole antenna and its frequency bandwidth under $-10 \mathrm{~dB}$ return loss is ranging from $3 \mathrm{GHz}$ to $11.6 \mathrm{GHz}$. This compact printed monopole antenna works well for the whole UWB frequency band $3.1-10.6 \mathrm{GHz}$.
\end{abstract}

Keywords: UWB, semicircular printed monopole antenna, microstrip line.

\section{Introduction}

Ultra-Wideband (UWB) commonly refers to signal or system that either has a large relative bandwidth (BW) or a large absolute bandwidth [1-4]. Such a large BW offers specific advantages with respect to signal robustness, information content and/or implementation simplicity. But such systems have some fundamental differences from the conventional narrowband systems. The Federal communications Commission (FCC) has designated the 3.1 to $10.6 \mathrm{GHz}$ band with Effective Isotropic Radiated Power (EIRP) below $-40 \mathrm{dbm} / \mathrm{kHz}$ for UWB Communications.

\section{Literature Review}

Some UWB antennas are much more complex than other existing single band, dual band and multi-band antennas [5, 6]. Most of the UWB monopole antennas are investigated till today is non-planar as in $[7,8]$ and due to its protruded structure they cannot be integrated with integrated circuits and they are fragile. Few researchers have also studied printed monopole Antennas

In this paper, we will investigate UWB antenna, which is basically a printed microstrip antenna with etched ground plane. First we will investigate in depth the semicircular disk printed monopole antenna for UWB applications. For getting compactness, we have etched the half of the part of circular patch without disturbing the bandwidth as well as antenna parameter. We have used con- ventional rectangular microstrip lines as feed lines for printed UWB antennas which are properly matched to the antenna impedance. In future we will also investigate other broadband matching techniques to further improve the UWB performance of the printed monopole antennas [9-11]. CAD-FEKO simulation software has been employed for obtaining the simulation results.

\section{Research Methodology}

This modified UWB monopole antenna is designed directly from the circular disc UWB-Monopole antenna with some modifications in the patch shape as shown in Figure 1. We have used the same FR4 substrate with 4.4 relative permittivity and $1.6 \mathrm{~mm}$ thickness. The real part of antenna impedance is exactly $50 \Omega$ at $8.5 \mathrm{GHz}$ and $10.8 \mathrm{GHz}$ when the imaginary part of antenna impedance cross zero. The final optimal dimensions of the UWBmonopole antenna are:

- dimensions of patch: radius $r=12 \mathrm{~mm}$; metal thickness $0.035 \mathrm{~mm}$;

- dimensions of substrate: $W_{1}=34 \mathrm{~mm} ; L_{1}=50 \mathrm{~mm}$;

- dimensions of ground: $W_{2}=34 \mathrm{~mm} ; L_{2}=26 \mathrm{~mm}$;

- microstrip line: $W_{3}=2.6 \mathrm{~mm} ; L_{3}=27.5 \mathrm{~mm}$, where $g$ is a gap between the ground plane and patch.

After doing an extensive simulation study, we have fixed the dimensions of UWB monopole antenna and the value of $g$ as $1 \mathrm{~mm}$. The antenna impedance, $f_{\text {low }}, f_{\text {high }}$ and radiation efficiency are tabulated in Table 1 . Note that proposed semicircular disc Monopole antenna is more 
compact and high efficient antenna for UWB applications. It has maximum directivity at $-26^{\circ}$ and $180^{\circ}$ at $3 \mathrm{GHz}$ and at the frequency $10.6 \mathrm{GHz}$, it has been tilted to $10^{\circ}$ and $-26.4^{\circ}$ as frequency increases it is slightly titled with $5^{\circ}$ to $10^{\circ}$. The $\mathrm{H}$-plane radiation pattern on the other hand is purely omni-directional pattern throughout the band of frequencies.

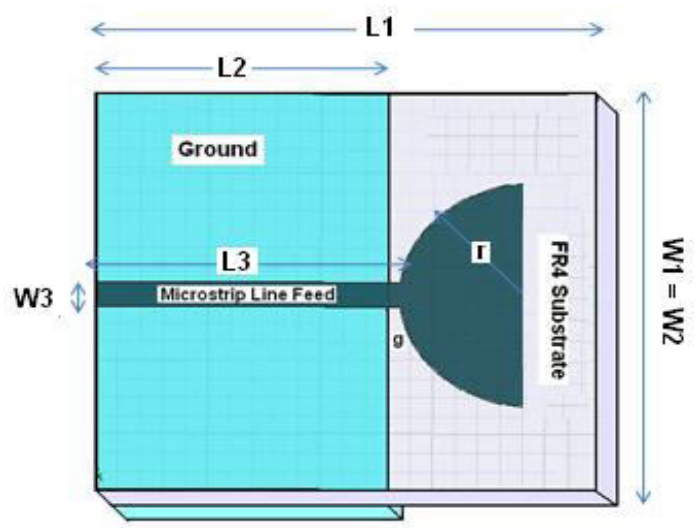

Figure 1 - Geometry of Circular UWB Antenna

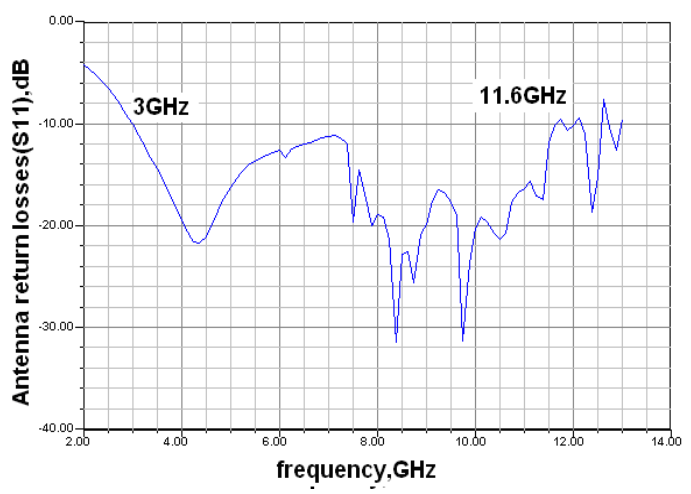

a

\section{Results}

The simulated 3D radiation patterns of the proposed antenna at $3.1,5,8,9,10.6$ and $11.2 \mathrm{GHz}$ are shown in Figures 2-4. The radiation pattern looks like a doughnut, similar to that of a dipole pattern, at the first resonant frequency, i. e. $3 \mathrm{GHz}$. At the second resonant frequency i.e. at $5 \mathrm{GHz}$ and the third resonance frequency, i. e. at $8 \mathrm{GHz}$ the radiation pattern is somewhat like pinched doughnut (i.e. omni directional). As the frequency moves toward the upper end of the bandwidth the radiation pattern is some what slightly distorted as it reaches higher frequencies (i. e.10.6 GHz and 11.2 GHz.).

The transition of the radiation patterns from a simple doughnut at the lower frequencies to the slowly distorted radiation patterns at the higher resonances indicates that this antenna must have gone through major changes in its behavior but it had omni directionality, this was possible because of the partial ground plane i.e. ' $\mathrm{g}$ ' the gap between the ground plane and the patch which was a major factor for perfect impedance matching of the antenna, due to the proper impedance matching the antenna has very less reflections. As the impedance matching was good the radiation power and radiation intensity were very high.

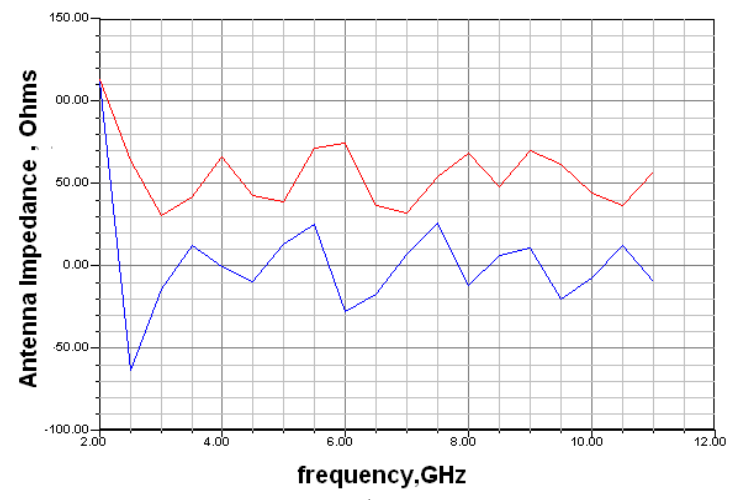

$\mathrm{b}$

Figure 2 - Return losses (a) and antenna impedance (b)

Table 1 - Parameters of the Circular Disc UWB monopole Antenna

\begin{tabular}{|c|c|c|c|c|c|c|c|c|}
\hline$g, \mathrm{~mm}$ & $F_{\text {low }}, \mathrm{GHz}$ & $F_{\text {high }}, \mathrm{GHz}$ & $\begin{array}{c}\text { Antenna } \\
\text { Impedance, } \Omega\end{array}$ & $P_{\text {acc }}, \mathrm{W}$ & $P_{\text {rad }}, \mathrm{W}$ & $\begin{array}{c}\mathrm{Max} U, \\
\mathrm{~W} / \mathrm{Sr}\end{array}$ & Peak Gain & $\eta, \%$ \\
\hline 0.8 & 3.2 & 11.5 & 50 & 0.98 & 0.88 & 0.13 & 1.69 & 89.6 \\
\hline 1 & 3 & 11.6 & 50 & 0.97 & 0.87 & 0.13 & 1.64 & 89.3 \\
\hline
\end{tabular}
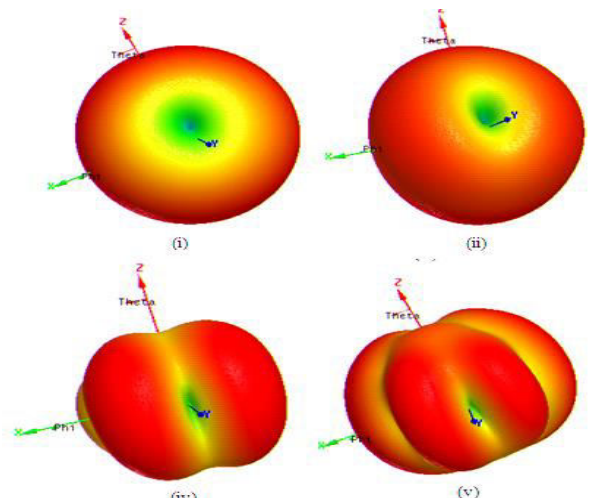

(ii)
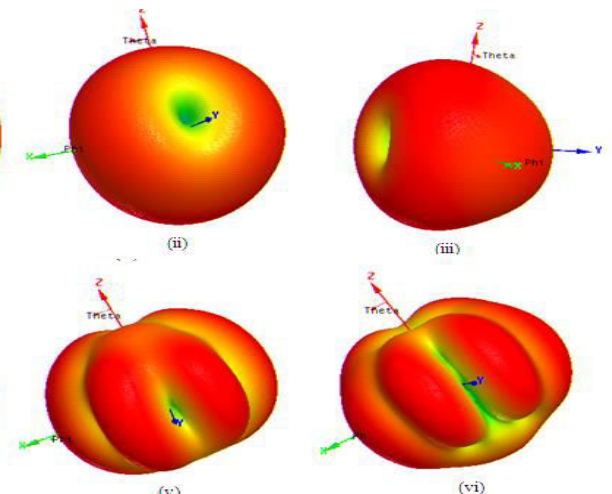

(iii)

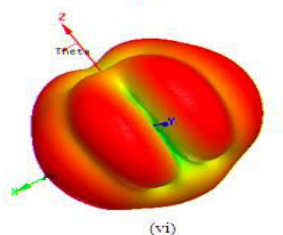

Figure 3 - 3D Radiation Plots 

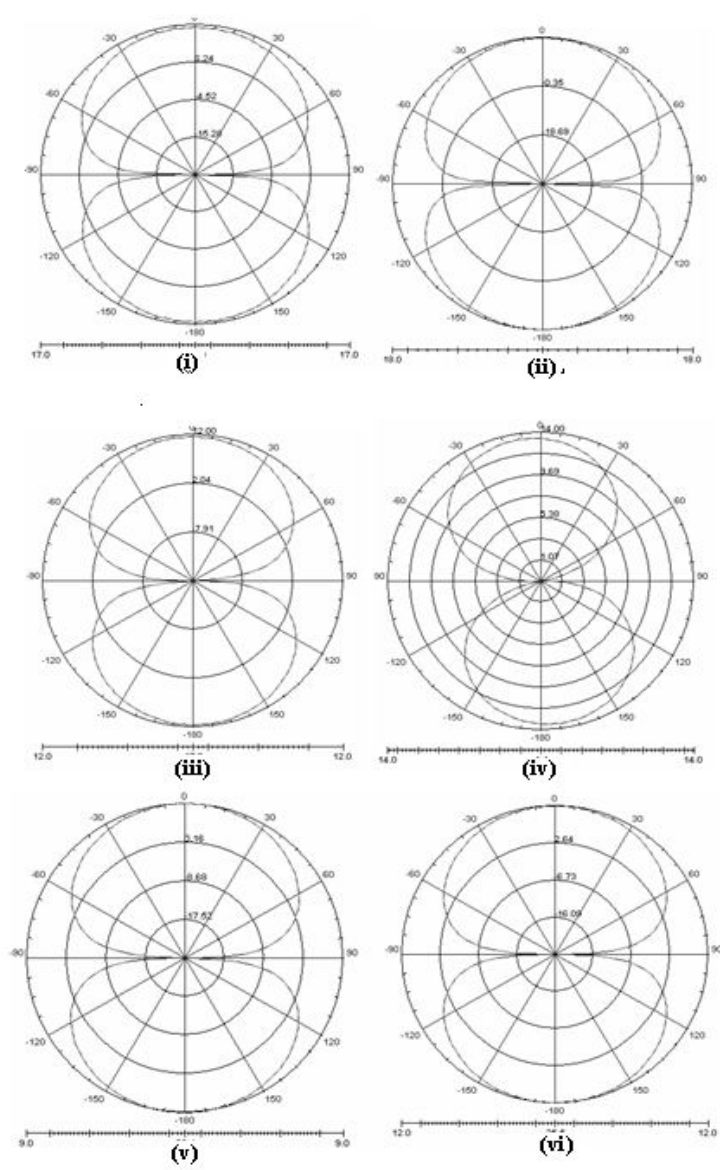

a
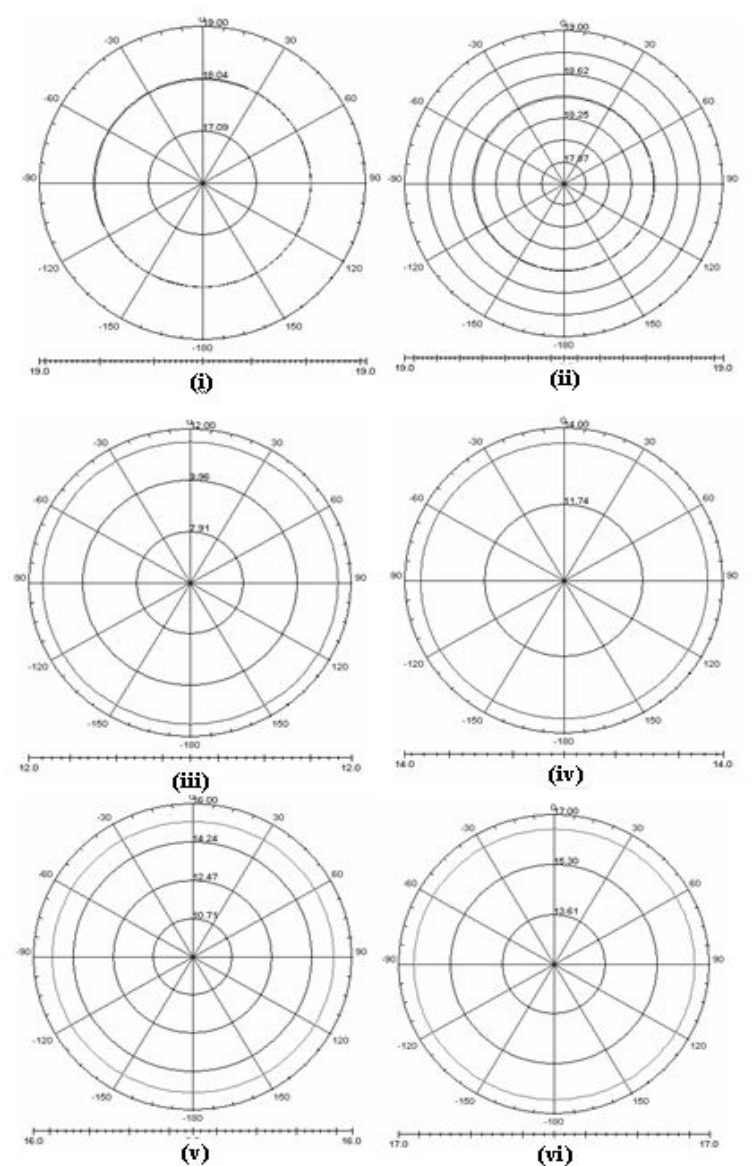

(vi)

b

Figure 4 - E-plane (a) and H-plane (b) radiation patterns

\section{Conclusions}

In this paper, the printed semicircular disc UWB monopole antenna with huge bandwidth has been investigated, which is basically the printed microstrip antenna with the etched ground plane. Printed UWB monopole antennas are less fragile, planar and can be integrated with the integrated circuits unlike monopole antennas which have non-planar or protruded structures above the ground plane. In particular, we have simulated very compact UWB monopole antenna and it has higher efficiency. The E-plane radiation the printed monopole antenna is in the form of 8 shapes and it is slightly tilted at higher frequencies. The H-plane radiation pattern has omnidirectional patterns throughout the frequencies of the BW. It has been observed that such monopole antennas are suitable for UWB operations.

\section{References}

1. Schantz, H. (2005). The Art and Science of Ultra wideband Antennas. Artech House Inc.

2. Aiello, G. R., \& Rogerson, G. D. (2007). Ultra-wideband Wireless Systems. IEEE Microwave Magazine, pp. 36-47.

3. Allen, B., Dohler, M., Okon, E. E., et al. (2007). Ultra-Wideband Antennas and Propagation for Communications. Radar and Imaging. John Wiley \& Sons Inc.

4. Pozar, D. M. (2005). Microwave Engineering. John Wiley \& Sons Inc.

5. Pillalamarri, R., \& Kshetrimayum, R. S. (2007). Printed UWB Circular and Modified Circular Disc Monopole Antennas. Accepted for IEEE Applied Electromagnetics Conference, Kolkatta, India.

6. Kshetrimayum, R. S., \& Pillalamarri, R. (2009). UWB printed monopole antenna with a notch frequency for coexistence with IEEE 802.1a WLAN devices. Proceedings of 5th National Conference on Communications (NCC). 
7. Pillalamarri, R., \& Kshetrimayum, R. S. (2007). Single Printed Monopole Antenna and Notched Antenna with Triangular Tapered Feed Lines for Triband and Penta band Applications. Proceedings of IEEE Indicon, Bangalore.

8. Pillalamarri, R., \& Kshetrimayum, R. S. (2007). Accurate Determination of Antenna Impedance of Microstrip Line-Fed Patch Antennas. Proceedings of IEEE Indicon 2007, Bangalore.

9. Liang, J., Chiau, C., Chen, X., \& Yu, J. (2004). Study of a circular disc monopole antennas for ultra wideband applications. International Symposium on Antennas and Propagation.

10. Agrawall, N. P., Kumar, G., \& Ray, K. P. (1998). Wide-Band Planar Monopole Antennas. IEEE Transactions on Antennas and Propagation, Vol. 46, No. 2, 294-295.

11. Hammoud, M., Poey, P., \& Colombel, F. (1993). Matching the Input Impedance of a Broadband Disc Monopole. Ellectronics Letters, Vol. 29, No. 4, 406-407.

12. CAD-FEKO Suite 4.2. Feko Corporation, South Africa.

\section{Модифікована плоска кругова UWB-антена}

\section{Піллаламаррі, Л.}

Відділ електроніки та зв'язку, Лабораторія радіочастот і мікрохвиль, м. Хайдарабад, Індія

Анотація. У роботі досліджено компактну друковану напівкруглу дискову антену, що є UWB-антеною із заземленням. Зокрема, змодельовано дуже компактні антени з напівкруглими дисками для UWB-зв'язку. Проста прямокутна мікрополосковая лінія використовується для живлення антени з частотною пропускною смугою -10 дБ із втратами від 3 ГГц до 11.6 ГГц. Ця модифікована антена добре працює для всього діапазону UWB-частот $3.1-10.6 \mathrm{GHz}$.

Ключові слова: UWB, модифікована антена, мікрополосковая лінія. 